\title{
The Effects of Admixtures Addition on Slump Decrease and Concrete Compressive Strength at B-1 Concrete Works
}

\author{
Basuki Setiyo Budi \\ Department of Civil Engineering, State Polytechnic of Semarang, Indonesia \\ Tel: 62-896-8696-3733Ｅ-mail: bsbudi24@yahoo.com
}

Supriyadi

Department of Civil Engineering, State Polytechnic of Semarang, Indonesia Tel: 62-812-283-9682Ｅ-mail: supriyadi083@yahoo.com

Edy Suhartono

Department of Civil Engineering, State Polytechnic of Semarang, Indonesia Tel: 62-815-7516-1357Ｅ-mail: edymaryamah@gmail.com

\begin{abstract}
Mawardi
Department of Civil Engineering, State Polytechnic of Semarang, Indonesia Tel: 62-812-283-5716 E-mail: mmawardi7@gmail.com
\end{abstract}

Sukoyo

Department of Civil Engineering, State Polytechnic of Semarang, Indonesia Tel: 62-878-3229-5845_E-mail: sukoirmtsuwarno@gmail.com

Bintang

Department of Civil Engineering, State Polytechnic of Semarang, Indonesia Tel: +6281327076096Ｅ-mail: bintang.atdi.pp@gmail.com 
Sakdiyah

Department of Civil Engineering, State Polytechnic of Semarang, Indonesia

Tel: 62-812-2506-2882Ｅ-mail: halimatusdiyah@gmail.com

Received: August 27, 2019 Accepted: October 10, 2019 Published: October 15, 2019

doi:10.5296/emsd.v8i4.15337ＵRL: https://doi.org/10.5296/emsd.v8i4.15337

\begin{abstract}
Semarang - Solo Toll Road is part of the Trans Java highway, which has a strategic meaning in the development of road networks, specifically in Central Java and also on a regional scale. The construction project generally consists of excavation work, stockpiles and bridge work. The number of work in the project therefore allows the emergence of a problem that can hinder the development process and one of which was related to concrete casting in the construction of the Kali Putih Bridge 1, where there was a slump decrease in columns P1 and P3 concrete pre-casting (30 Mpa). However, a slump test was carried out on column P1 in STA. $61+368,500$, and P3 in STA. $61+293,500$, which resulted in $3.5 \mathrm{~cm}$ and $4 \mathrm{~cm}$ collapse respectively. Hence, they did not meet specification on B-1 concrete, which was $7.5 \pm 2.5 \mathrm{~cm}$. In addition, Superplasticizer was used to overcome this problem, as it was capable of restoring freshness/workability. This study, therefore, aimed to determine the effect of the incorporating superplasticizer and retarder into concrete, on its compressive strength, slump decrease, and time, utilizing 24 test cylindrical specimens (7-days and 14-days), through pressure testing. Furthermore, the slump testing was conducted every 20 minutes for 120 minutes, to determine the reduction time, and the findings further indicated that adding a retarder to class B-1 concrete was capable of increasing the functional period (67 minutes on a slump of $7 \pm 2.5 \mathrm{~cm}$ ). However, the addition of Superplasticizer was also able to repair the slumps, which did not meet the requirements, including the specimen that involved the incorporation of a retarder $(82.5$ minutes, which resulted in a $1.9 \mathrm{~cm}$ slump that was further increased to $17.5 \mathrm{~cm}$ after augmentation. Furthermore, these effects were due to its ability to reduce the compressive strength by $3.13 \%$ and $6.14 \%$ on the 7 -days and 14-day specimens, respectively. However, the SPSS v.23.0 test results showed the difference in compressive strength between the normal concrete + retarder and normal concrete + retarder + SP, with a sig value of $0.021<\mathrm{a}=0.05$ (Turkey HSD Test) and $0.0009<\mathrm{a} 0.05$ (LSD Test).
\end{abstract}

Keywords: concrete, compressive strength, slump, retarder, superplasticizer

\title{
1. Introduction
}

Semarang - Solo Toll Road is part of the Trans Java highway, which has a strategic meaning for the development of road networks, specifically in Central Java, and also on a regional scale. The construction Project is divided into 4 sections, namely the Semarang-Ungaran, Ungaran-Bawen, Bawen- Salatiga, Salatiga-Boyolali and Boyolali-Kartasura Section. The 
construction also consisted of excavation, pile and bridge work. Furthermore, the number of the project allows the emergence of a problem that hinders the development process, one of which arise in relation to concrete casting, during the construction of Kali Putih Bridge 1, where there was a decrease in a slump in B-1 concrete (30 Mpa) before casting, observed in columns P1 and P3. A pre-casting test for column P1 in STA. $61+368,500$ and P3 in the STA. $61+293,500$ resulted in $3.5 \mathrm{~cm}$ and $4 \mathrm{~cm}$ slump respectively, while the specification on $\mathrm{B}-1$ concrete was $7.5 \pm 2.5 \mathrm{~cm}$, which does not meet the requirements. The Superplasticizer was used to overcome the problem as it was capable of restoring the freshness of the concrete. Hence, its use must be tested to determine the relationship between the quality of the concrete produced and the expectation. Furthermore, the slump decrease shows a decline in workability, caused by water evaporation, at a change in temperature and time - hence, good time management in transporting the fresh concrete, is required to maintain its functionality.

\section{Research Methodology}

\subsection{Research Tools and Materials}

The equipment and materials used for the research were as follows.

a. Tools: mixer, cylindrical mold $15 \times 30 \mathrm{~cm}$, press machine, stirring stick, grading spoon, Abraham cone, stopwatch, press machine, and other assistive devices.

b. Materials for making B-1 concrete in the Salatiga - Kartasura Section construction project are as follows:

Fine Aggregate: Ex Boyolali Sand

Rough Aggregates: Ungaran Split

Cement: Tiga Roda

Water: Ampel Batching Plant

Additive: Sika

\subsection{Research Design}

The study involved the use of 24 test cylinders, which were given pressure test for 7 and 14 days to determine the effect of adding admixtures on compressive strength. Furthermore, testing was carried out periodically, i.e., every 20 minutes for 6 consecutive times, in order to determine the time for slump reduction. 
Table 1. Testing Matrix

\begin{tabular}{|c|c|c|c|c|c|c|c|c|c|c|}
\hline \multirow{3}{*}{ No. } & \multirow{3}{*}{$\begin{array}{l}\text { Stirring } \\
\text { Time } \\
\text { (Minute) }\end{array}$} & \multicolumn{9}{|c|}{ Concrete Compressive Strength (Mpa) } \\
\hline & & \multicolumn{3}{|c|}{ Normal Concrete (NC) } & \multicolumn{3}{|c|}{ NC+Retarder } & \multicolumn{3}{|c|}{$\begin{array}{c}\text { NC+Retarder+ } \\
\text { Superplasticizer }\end{array}$} \\
\hline & & slump & 7 days & 14 days & slump & 7 days & 14 days & slump & 7 days & 14 days \\
\hline 1 & \multirow{4}{*}{2.5} & \multirow{4}{*}{1} & 1 & 1 & \multirow{4}{*}{1} & 1 & 1 & \multirow{4}{*}{ - } & - & - \\
\hline 2 & & & 1 & 1 & & 1 & 1 & & - & - \\
\hline 3 & & & 1 & 1 & & 1 & 1 & & - & - \\
\hline 4 & & & 1 & 1 & & 1 & 1 & & - & - \\
\hline 5 & 22.5 & 1 & - & - & 1 & - & - & - & - & - \\
\hline 6 & 42.5 & 1 & - & - & 1 & - & - & - & - & - \\
\hline 7 & 62.5 & 1 & - & - & 1 & - & - & - & - & - \\
\hline \multirow{3}{*}{8} & \multirow{3}{*}{82.5} & \multirow{3}{*}{1} & - & - & \multirow{3}{*}{1} & - & - & \multirow{3}{*}{1} & 1 & 1 \\
\hline & & & - & - & & - & - & & 1 & 1 \\
\hline & & & - & - & & - & - & & 1 & 1 \\
\hline 9 & 102.5 & 1 & - & - & 1 & - & - & 1 & 1 & 1 \\
\hline 10 & 122.5 & 1 & - & - & 1 & - & - & 1 & - & - \\
\hline 11 & 142.5 & - & - & - & - & - & - & 1 & - & - \\
\hline 12 & 162.5 & - & - & - & - & - & - & 1 & - & - \\
\hline 13 & 182.5 & - & - & - & - & - & - & 1 & - & - \\
\hline 14 & 202.5 & - & - & - & - & - & - & 1 & - & - \\
\hline
\end{tabular}

Source: The calculation results (2018)

The specimens used include concrete cylinders of 15 x $30 \mathrm{~cm}$, with quality of B-1 (30 MPa). Furthermore, the components used include Retarder and Superplasticizer, while the matrices of compressive strength and slump testing are shown in table 1.

A total of 24 test specimens were made for this study, and the details are as follows.

1. Eight normal samples, with four kept for 7-days, and the remainder for 14-days.

2. Eight specimens with retarder, four were kept for 7-days test, and four for 14-days.

3. Eight varieties with Retarder + Superplasticizer, where four were retained for 7-days, and the remainder for 14-days.

The Retarder + Superplasticizer specimen were made from its admixture plus retarder, mixed for 120 minutes, according to field requirements.

\section{Result and Discussion}

\subsection{Result}

The test method used refers to SNI 03-1974-1990, as regards concrete compressive strength. However, the 7-days and 14-days specimens were subjected to concrete compressive testing machines in the Civil Engineering Laboratory of Semarang State Polytechnic, where the results obtained were as follows. 
Table 2. Compressive strength test results

\begin{tabular}{|c|c|c|c|c|c|c|c|c|c|c|}
\hline & mix & \multicolumn{8}{|c|}{ Concrete Compressive Strength (Mpa) } \\
\cline { 4 - 12 } No. & $\begin{array}{l}\text { design } \\
\text { plan } \\
\text { (Max) }\end{array}$ & \multicolumn{3}{|c|}{ Normal Concrete (NC) } & \multicolumn{5}{|c|}{ NC+Retarder } & \multicolumn{3}{|c|}{$\begin{array}{c}\text { NC+Retardert } \\
\text { Superplasticizer }\end{array}$} \\
\cline { 3 - 12 } & slump & 7 days & 14 days & slump & 7 days & 14 days & slump & 7 days & 14 days \\
\hline 1 & 30 & 8.9 & 30.45 & 29.49 & 14.4 & 29.78 & 31.34 & 17.5 & 29.78 & 29.68 \\
\hline 2 & 30 & 8.9 & 29.79 & 30.23 & 14.4 & 31.03 & 30.48 & 17.5 & 29.28 & 26.73 \\
\hline 3 & 30 & 8.9 & 30.02 & 30.83 & 14.4 & 31.78 & 29.80 & 17.5 & 27.29 & 29.06 \\
\hline 4 & 30 & 8.9 & 30.01 & 29.98 & 14.4 & 30.61 & 30.72 & 17.5 & 29.20 & 29.37 \\
\hline
\end{tabular}

Source: test result (2018)

The slump test was carried out 6 times at 20 minutes interval, and the first stirring was assumed at 2.5 minutes. However, the compressive strength test was based on the results obtained from the initial assessment and the remaining concrete in the mixer was further stirred for 20 minutes and slump tested, and this process was carried out until it no longer met the requirements. Furthermore, superplasticizers were added to the Normal + Retarder concrete sample that did not meet the specification, and the results were as follows.

Table 3. Slump test result

\begin{tabular}{|c|c|c|c|c|}
\hline \multirow{2}{*}{ No. } & \multirow{2}{*}{$\begin{array}{c}\text { test duration } \\
\text { (minutes) }\end{array}$} & $\begin{array}{c}\text { Normal Concrete } \\
\text { (NC) }\end{array}$ & NC+ Retarder & NC+ Retarder + Superplasticizer \\
\hline 1 & 2.5 & 8.9 & 14.4 & \\
\hline 2 & 22.5 & 6.1 & 11.4 & \\
\hline 3 & 42.5 & 2.9 & 8.1 & \\
\hline 4 & 62.5 & 0.4 & 5.9 & 17.5 \\
\hline 5 & 82.5 & 0 & 1.9 & 16.3 \\
\hline 6 & 102.5 & & 0 & 14.8 \\
\hline 7 & 122.5 & & & 11.8 \\
\hline 8 & 142.5 & & & 6.9 \\
\hline 9 & 162.5 & & & 2.6 \\
\hline 10 & 182.5 & & & 0 \\
\hline 11 & 202.5 & & & \\
\hline
\end{tabular}

Source: Slump test result (2018)

\subsection{Discussion}

\subsubsection{Slump Analysis}

Analysis of slump testing was carried out through tabulation of the three samples, which were 
then interpreted in graph format, compared and conclusions were drawn. Furthermore, the effect was observed to decrease at the time function, as reported below.

1. Normal concrete (without the addition of admixtures) showed the following:

Table 4. Slump test results on normal concrete

\begin{tabular}{|c|c|}
\hline Time (minutes) & Slump (cm) \\
\hline 2.5 & 8.9 \\
\hline 22.5 & 6.1 \\
\hline 42.5 & 2.9 \\
\hline 62.5 & 0.4 \\
\hline 82.5 & 0 \\
\hline
\end{tabular}

Source: Slump test results (2018)

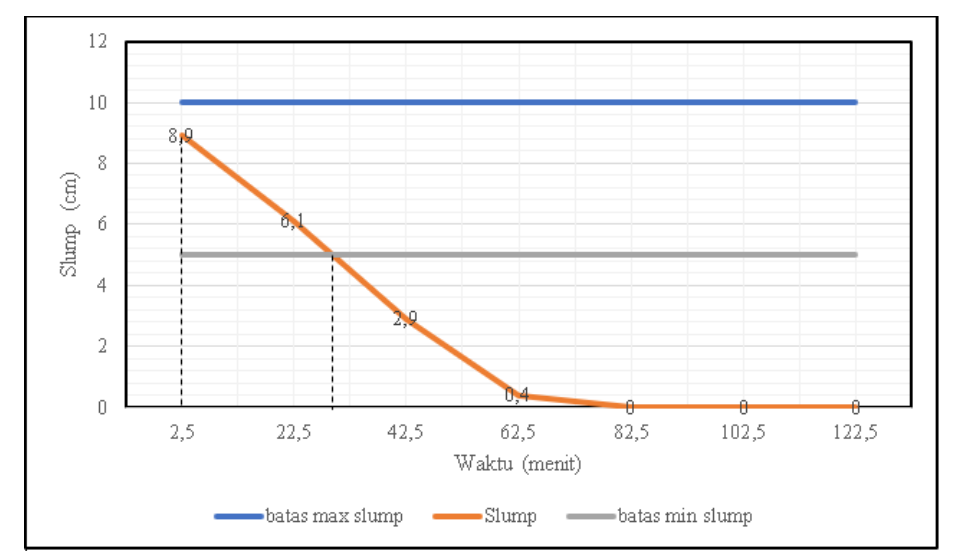

Figure 1. Graph showing the relationship between Normal Concrete Slump against Time (Field Results)

At the exponent of time, the graph showing the effect of the normal concrete slump indicated a relatively fast binding capacity. However, the requirements assessing B-1 grade concrete in the field were $7.5 \pm 2.5 \mathrm{~cm}$ and those that met the specifications, only lasted for 29.4 minutes.

2. Concrete with retarder

The results of testing slumps on concrete with a mixture of retarders are as follows. 
Table 5. Normal + Retarder Concrete Slump Test Results

\begin{tabular}{|l|l|}
\hline Time (minutes) & Slump(cm) \\
\hline 2.5 & 14.4 \\
\hline 22.5 & 11.4 \\
\hline 42.5 & 8.1 \\
\hline 62.5 & 5.9 \\
\hline 82.5 & 1.9 \\
\hline 102.5 & 0 \\
\hline 122.5 & - \\
\hline
\end{tabular}

Source: Slump test result (2018)

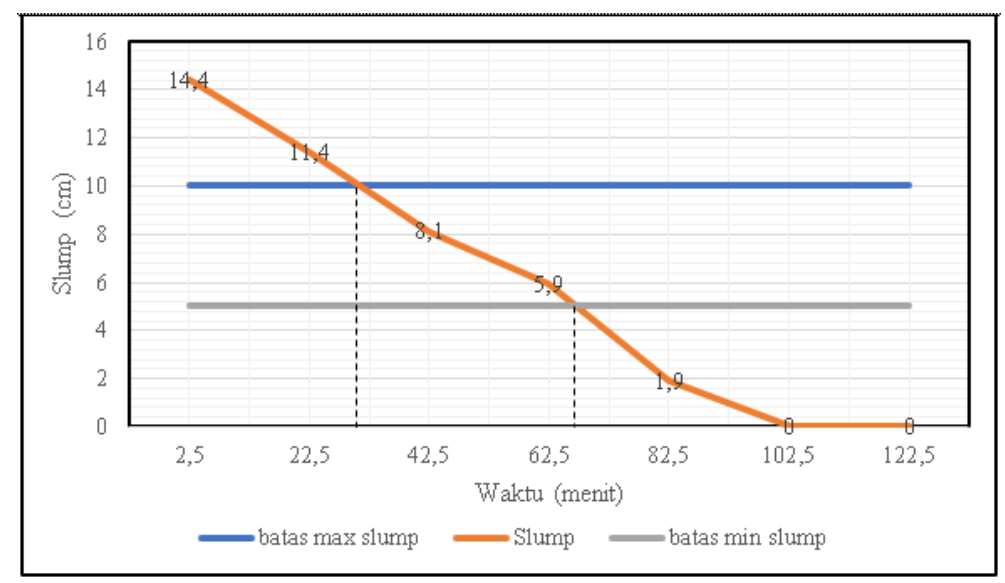

Figure 2. Graph showing the effect of Normal Concrete + Retarder Slump against Time (Field Results)

The graph above indicated that concrete has relatively fast binding conditions. The requirements for slump testing in concrete B-1 class in the field were $7.5 \pm 2.5 \mathrm{~cm}$. The graph above shows that slumps that meet the requirements can only last for 29.4 minutes.

3. Concrete with a mixture of retarder + superplasticizer

Superplasticizer was added to normal + retarder concrete samples for 82.5 minutes, in order to obtain slump test results that did not meet the requirements or show a value of $1.9 \mathrm{~cm}$, with results as follows.

Table 6. The Test Results of Normal Concrete Slump + Retarder + Superplasticizer

\begin{tabular}{|l|l|}
\hline Time (minutes) & Slump(cm) \\
\hline 82.5 & 17.5 \\
\hline 102.5 & 16.3 \\
\hline 122.5 & 14.8 \\
\hline 142.5 & 11.8 \\
\hline 162.5 & 6.9 \\
\hline 182.5 & 2.6 \\
\hline 202.5 & 0 \\
\hline
\end{tabular}

Source: Slump test results (2018) 


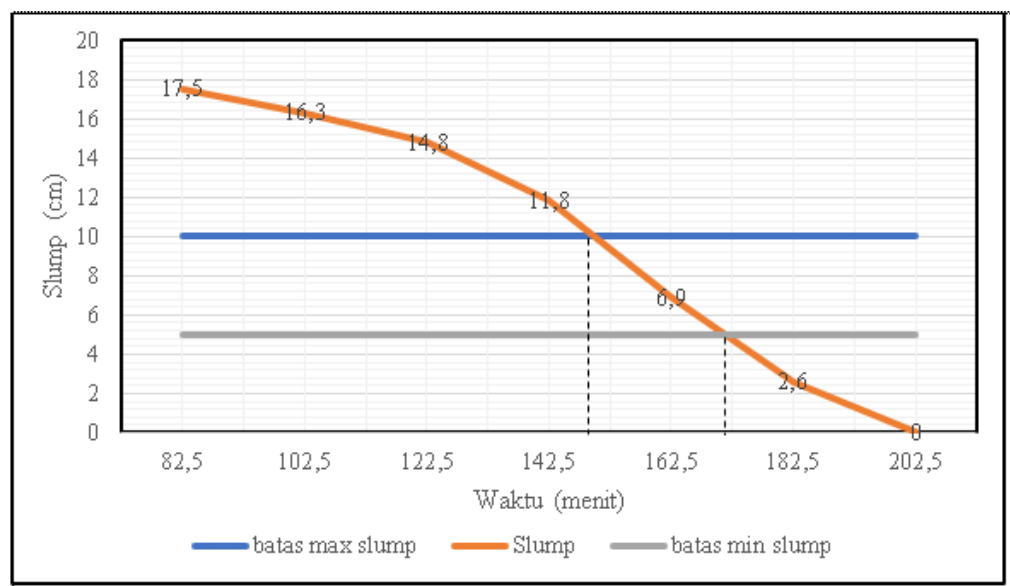

Figure 3. The graph showing the Relationship between Normal Concrete Slump + Retarder + Superplasticizer and Time (Field Results)

Figure 3 shows that the mixture has a slower binding strength than the normal concrete. However, the requirement for slump testing in the B-1 class at the field was $7.5 \pm 2.5 \mathrm{~cm}$. therefore, the results that met the requirements specifications lasted for 91.3 minutes, if the time at which the superplasticizer was added (82.5), is assumed to be 0 .

4. The slump decrease in the all-three samples

The addition of admixture in the concrete lead to a higher initial slump condition, as fresh concrete contains more water therefore, it lasts longer in the mix, when compared to normal concrete. Furthermore, the results of the data combination of the slump decrease are as follows.

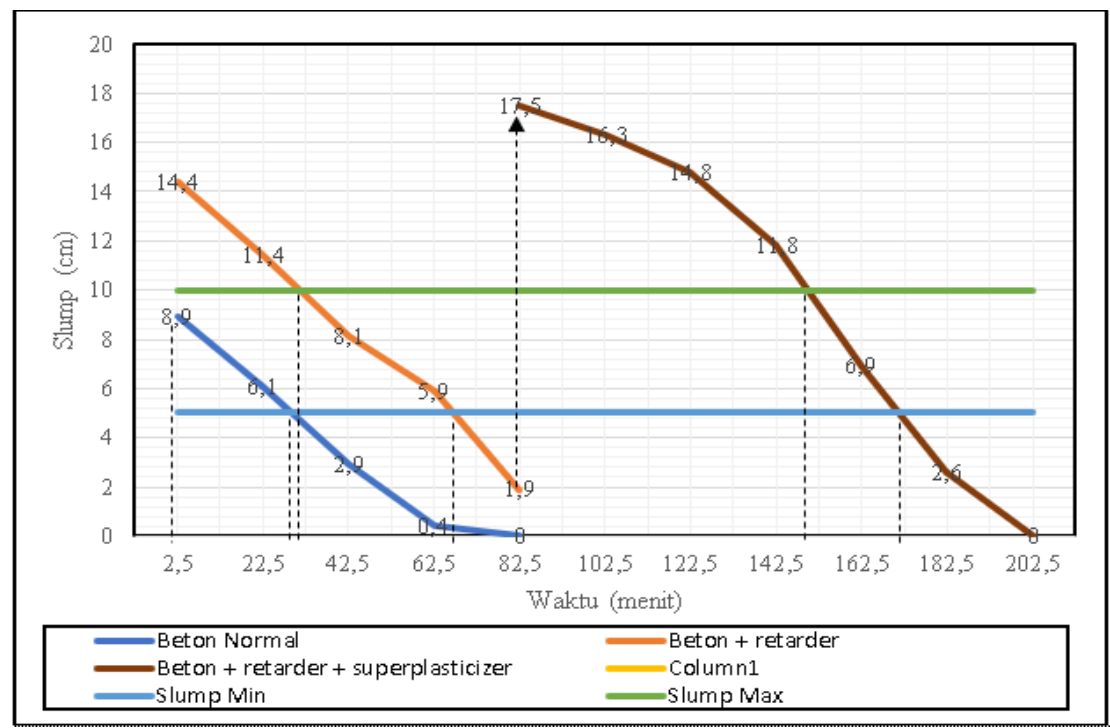

Figure 4. Combined slump decrease graph (Combined Graph Results) 


\section{Macrothink}

The addition of a superplasticizer restores the dilution of fresh concrete, as it is even more diluted than the initial slump produced. However, a mixture containing a retarder in the 82.5th minute resulted in a $1.9 \mathrm{~cm}$ collapse - hence, it did not meet the required specifications. Therefore, it required the addition of a superplasticizer to increase the value to $17.5 \mathrm{~cm}$.

\subsubsection{Compressive Strength Analysis}

Analysis of compressive strength was carried out through tabulation of the three samples, which were tested, averaged, and graphically represented accordingly. Therefore, the data obtained were compared and concluded, while the effect of adding the admixture was illustrated as follows.

\section{Normal concrete (without admixtures)}

The normal concrete samples were taken from the first spin in 2.5 minutes, with a slump of 8.9 and the results of compressive strength testing are as follows.

Table 8. Normal concrete compressive Strength test result

\begin{tabular}{|c|c|c|c|c|}
\hline \multirow{2}{*}{ No. } & \multirow{2}{*}{$\begin{array}{c}\text { Concrete } \\
\text { Quality }\end{array}$} & \multicolumn{2}{|c|}{$\begin{array}{c}\text { compressive } \\
\text { strength of }\end{array}$} & \multirow{2}{*}{ Defective } \\
\cline { 3 - 4 } & Required (Mpa) & 7 days & 14 days & \\
\hline 1 & 30 & 30.45 & 29.49 & - \\
\hline 2 & 30 & 29.79 & 30.23 & - \\
\hline 3 & 30 & 30.02 & 30.83 & - \\
\hline 4 & 30 & 30.01 & 29.98 & - \\
\hline \multicolumn{2}{|c|}{ Average } & 30.07 & 30.13 & \\
\hline
\end{tabular}

Source: Compressive strength test result (2018)

The table shows that the compressive strength at the 7-days and the 14-days specimens that have been converted to 28 days was fulfilling the requirements, namely 30.07> $30 \mathrm{Mpa}$ and 30.13> $30 \mathrm{Mpa}$.

2. Concrete with a mixture of retarders

The sample of a mixture of retarder was taken in minute 2.5 with a slump of 14.4 . The results of the compressive strength test are as follows.

Table 9. Normal + Retarder Concrete Compressive Strength Test Results

\begin{tabular}{|c|c|c|c|c|}
\hline \multirow[t]{2}{*}{ No. } & \multirow{2}{*}{$\begin{array}{c}\text { Concrete } \\
\text { Quality } \\
\text { Required (Mpa) }\end{array}$} & \multicolumn{2}{|c|}{$\begin{array}{l}\text { compressive } \\
\text { strength of }\end{array}$} & \multirow[t]{2}{*}{ Defective } \\
\hline & & 7 days & 14 days & \\
\hline 1 & 30 & 29.78 & 31.34 & - \\
\hline 2 & 30 & 31.03 & 30.48 & - \\
\hline 3 & 30 & 31.78 & 29.80 & - \\
\hline 4 & 30 & 30.61 & 30.72 & - \\
\hline \multicolumn{2}{|r|}{ Average } & 30.80 & 30.58 & \\
\hline
\end{tabular}

Source: Compressive strength test result (2018) 


\section{Macrothink}

Environmental Management and Sustainable Development

ISSN 2164-7682

2019, Vol. 8, No. 4

The compressive strength test results show that the 7-days and 14-days specimens, which have been converted to 28 days, met the requirements (30.80>30 Mpa and 30.58>30 Mpa).

3. Concrete with a mixture of retarder + superplasticizer

The samples were taken at the 82.5th minute, and the superplasticizer was added to create 17.5 of the slump, and the results of the compressive strength test are as follows.

Table 10. Normal + Retarder + Superplasticizer Concrete Compressive Strength Test

\begin{tabular}{|c|c|c|c|c|}
\hline \multirow[t]{2}{*}{ No. } & \multirow{2}{*}{$\begin{array}{c}\text { Concrete } \\
\text { Quality } \\
\text { Required (Mpa) }\end{array}$} & \multicolumn{2}{|c|}{$\begin{array}{c}\text { compressive } \\
\text { strength of }\end{array}$} & \multirow[t]{2}{*}{ Defective } \\
\hline & & 7 days & 14 days & \\
\hline 1 & 30 & 29.78 & 29.68 & - \\
\hline 2 & 30 & 29.28 & 26.73 & Porous (14 day sample) \\
\hline 3 & 30 & 27.29 & 29.06 & Porous (7 day sample) \\
\hline 4 & 30 & 29.20 & 29.37 & - \\
\hline \multicolumn{2}{|r|}{ Average } & 28.89 & 28.71 & \\
\hline
\end{tabular}

Source: Compressive strength test result (2018)

The compressive strength of the 7-days and 14-days specimens that have been converted to 28-days did not meet the requirements $(28.89<30 \mathrm{Mpa}$ and $28.71<30 \mathrm{Mpa})$, as they showed a loss.

4. Effect of adding admixtures on compressive strength

The average results of the three tests combined is seen in the table and graph below

Table 11. The effect of Admixture addition on Compressive strength

\begin{tabular}{|c|l|c|c|c|}
\hline No. & $\begin{array}{c}\text { Average } \\
\text { Compressive } \\
\text { strength of }\end{array}$ & $\begin{array}{c}\text { Normal Concrete } \\
\text { (NC) }\end{array}$ & NC+ Retarder & $\begin{array}{c}\text { NC + Retarder + } \\
\text { Superplastcizer }\end{array}$ \\
\hline 1 & Concrete 7 days & 30.07 & 30.80 & 28.89 \\
\hline 2 & Concrete 14 days & 30.13 & 30.58 & 28.71 \\
\hline
\end{tabular}

Source: The calculation results (2018) 


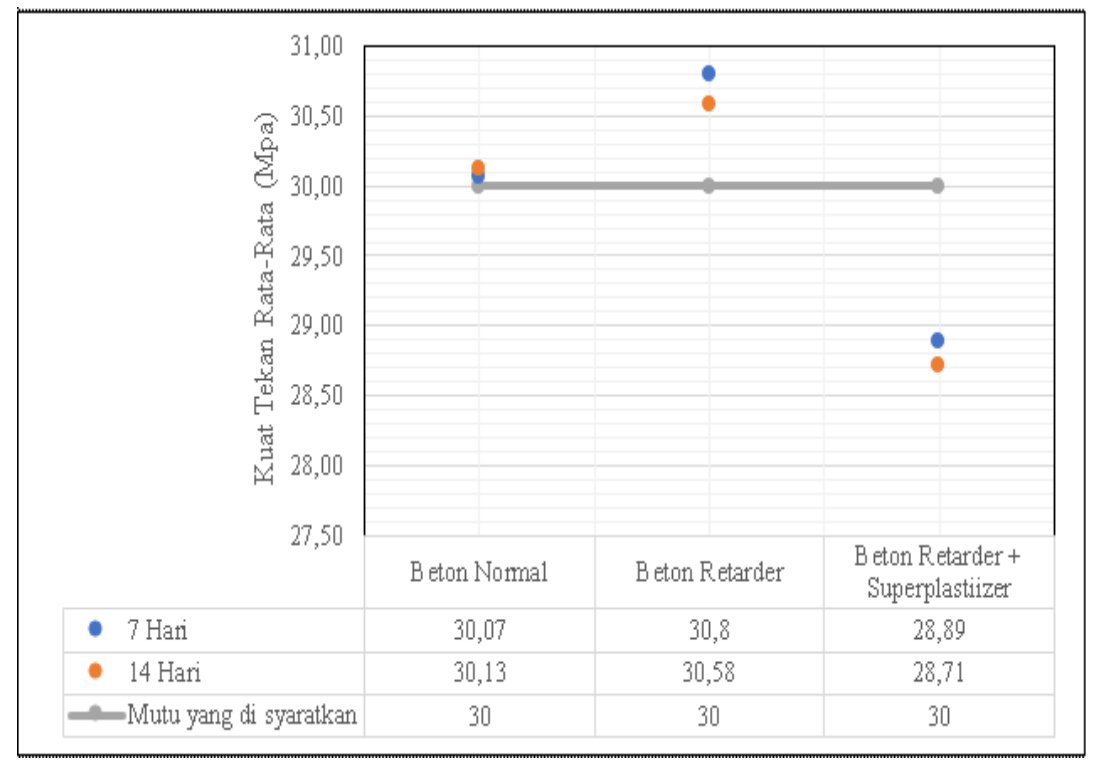

Figure 5. The effect of admixture addition on Compressive strength (field result)

The effect of the Admixture addition on compressive strength is illustrated in figure 4.5, where the average was shown to be higher on the 7-days and 14-days specimens, to which retarder was added, than normal concrete, with an average of $30.08 \mathrm{Mpa}$ and $30.58 \mathrm{Mpa}$. However, the addition of superplasticizers showed a lower value than the normal and the one to which retarders were added.

The addition of the retarder increased the compressive strength of concrete by $3.65 \%$ and $2.4 \%$ in the 7-day and 14-day specimen respectively, which were both higher than the normal concrete. However, the addition of superplasticizers reduced the compressive strength of concrete by $3.13 \%$ and $3.9 \%$ for 7-day and 14-day specimens respectively, which were both lower than the normal concrete. Furthermore, this additive reduced the value on concrete by $7.01 \%$ and $6.14 \%$ for the 7-day and 14-day specimens respectively, which were both lower than a mixture with retarder. Hence, the decrease was probably due to segregation, as a result of an increase in slump value $(17.5 \mathrm{~cm})$, caused by the incorporation of superplasticizers and its utility in casting, shortly after the mixing process was complete.

\subsubsection{ANOVA Analysis}

The ANOVA test was conducted to compare various data obtained, However, the concrete compressive strength of normal concrete + retarders and normal concrete + retarder + SP are differentiated, based on Tukey HSD Test, where the sig value $=0.021<\alpha=0.05$ and LSD test, which showed a sig value $=0.009<\alpha=0.05$ as seen in Table 11 . 
Table 11. Results of SPSS Analysis of the ANOVA Method

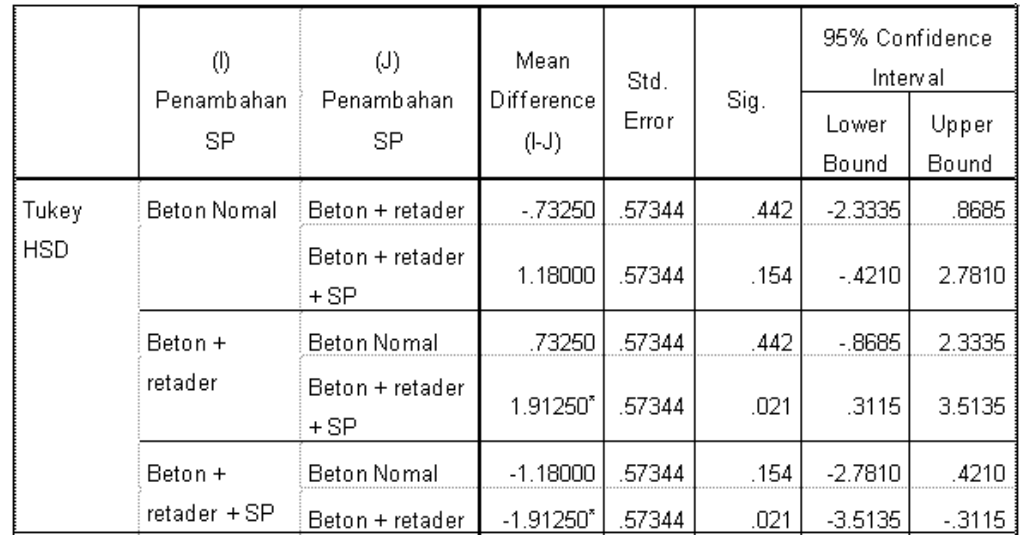

Source: SPSS v.24 result (2018)

\section{Conclusion}

Based on the results and the discussion above, the following conclusions were made.

1. The workability of the class B-1 fresh concrete at normal condition (without Admixture) lasted for 29.4 minutes and the that of concrete + retarder was 67 minutes, with a slump requirement of $7 \pm 2.5 \mathrm{~cm}$, while that which include superplasticizer was capable of repairing the category that did not fulfill the required specification $(1.9 \mathrm{~cm}$ of concrete with a mixture of retarders at 82.5) to $17.5 \mathrm{~cm}$.

2. The addition of superplasticizer reduced the concrete compressive strength of the 7 and the 14-day specimens, in the presence of retarders, by $7.01 \%$ and $6.14 \%$ respectively.

\section{Suggestion}

The following were suggested based on the results and discussions.

1. Fresh concrete should be delivered from the Batching Plan to the casting location in no more than 67 minutes, in order to maintain a condition that meets the casting requirements, with a slump of $7 \pm 2.5 \mathrm{~cm}$ due to its influence on the workability.

2. The incorporation of superplasticizers in an attempt to repair fresh concrete slump reduces compressive strength due to segregation. Hence, there is a need for further research on the addition of appropriate superplasticizers to avoid decreasing of concrete compressive strength.

3. Subsequent studies are therefore expected to assess the compressive strength of the B-1 grade standard slump $(7.5 \pm 2.5)$, in order to obtain more accurate results.

\section{References}

National Standardization Agency. (2008). SNI 1972:2008 How to Test Concrete Slump. Bandung: National Standardization Agency.

National Standardization Agency (2000). SNI 03-2834-2000 The Procedure for Making a Normal Concrete Mix Plan. Bandung: National Standardization Agency. 


\section{Macrothink}

Environmental Management and Sustainable Development

ISSN 2164-7682

2019, Vol. 8, No. 4

National Standardization Agency (1990). SNI 03 - 1972 - 1990 Concrete Slump Testing Method. Bandung: National Standardization Agency.

National Standardization Agency (1990). SNI 03 - 1974 - 1990 Concrete Compressive Strength Testing Method. Bandung: National Standardization Agency.

PT. Solo Ngawi Jaya. (2016). Procurement Services for Semarang-Solo Toll Road Project for Salatiga - Kartasura Toll Road. Surakarta.

Hardy, A. (2006). Pengaruh Persentase Bahan Retarder Terhadap Biayadan Waktu Pengerasan Campuran Beton. (Abstrak). Faculty of Engineering Civil Department, Maranatha Christian University, Bandung.

Humaidi, Muhammad dan Muhammad Hafizh. (2011). Pengaruh Nilai Slump Terhadap Kuat Tekan. Jurnal INTEKNA, 9(2), 140-145.

Kusdiyono. (2012). Bahan Bangunan 2. Semarang :Penerbit Polines.

Marsiano. (2010). Penggunaan Admixtures Superplasticizer Pada Beton Untuk Menaikkan Mutu Beton. page 128-147. Faculty of Civil Engineering and Planning National Institute of Science and Technology.

Mallisa, H. (2008). Pengaruh Lamanya Pengadukan Terhadap Nilai Slump dan Kandungan Udara Campuran Beton. Jurnal SMARTek, 6(2). 80-87.

Nugraha, Paul dan Antoni. (2007). Teknologi Beton dari Material, Pembuatan ke Beton Kinerja Tinggi. Yogyakarta: Andi Offset.

Product Data Sheet Sika. (2018). Plastiment VZ. Bogor: PT. Sika Indonesia.

Product Data Sheet Sika. (2016). SikamentLN. Bogor: PT. Sika Indonesia.

Safety Data Sheet Sika. (2017). Sika Retarder. Auckland: Sika (NZ) Ltd. SDS Number: 000000607469.

Safety Data Sheet Sika. (2017). Sikament NN. Elisabeth Street: Sika Australia Pty. Ltd. MSDS Number: 000000610816.

Sagel, R. P. K., \& Gideon, K. (1994). Pedoman Pengerjaan Beton Berdasarkan SKSNI T-15-1991-03. Jakarta: Erlangga.

Seltmant, H. (2018). Experimental Design and Analysis. Pitsburgh: Carneige Mellon University Statistics \& Data Science.

\section{Copyright Disclaimer}

Copyright for this article is retained by the author(s), with first publication rights granted to the journal.

This is an open-access article distributed under the terms and conditions of the Creative Commons Attribution license (http://creativecommons.org/licenses/by/3.0/). 